\title{
Logic of Intersubjective Limits within Habermas' Community (or Why We Should Not Be a Unified Whole)
}

\author{
Tatiana Weiser \\ Associate Professor, Russian Presidential Academy of National Economy and Public Administration \\ Address: Prospect Vernadskogo, 82, Moscow, Russian Federation 119571 \\ E-mail: tianavaizer@yandex.ru
}

\begin{abstract}
This article investigates the model of the transnational cosmopolitan moral-legal community of limitless communication. This model, using philosophical means, appears as an attempt to underscore the impossibility of authoritarian monopolies of power which resulted in the dictatorial regimes and national (pro)totalitarian communities of the 2oth century. I will reconstruct this model of the supranational community, and analyze the mode of morally-oriented intersubjective interactions within this community. I will show that the differentiation of limits between the "interior" (subjective) and the "exterior" (intersubjective) worlds is an essential communicative and ethical problem in Habermas' theory. According to this differentiation, subjective "verity" of an individual/local community may be defined and justified by purposes, axiological preferences, and tastes of a particular individual/community; while a claim pretending to be an intersubjective norm should be justified and voluntary accepted by all concerned with this norm. The non-differentiation of limits between what one believes to be "veritable", and what one claims others should accept as a norm (or imposing on others one's particular axiological position as a universal norm) underlies most social, (geo)political, ethnical, confessional conflicts, and communicative deformations. Until recently, academic literature did not pay much attention to this key aspect of Habermas' theory. At the same time, it is this differentiation between the subjectively "veritable" and the intersubjectively valid that makes Habermas' community anti-totalitarian, and reveals the deep political significance of intersubjective limits.
\end{abstract}

Keywords: Habermas, J. S. Mill, community, intersubjectivity, egocentrism, intersubjective limits

(C) Tatiana Weiser, 2014

(c) Centre for Fundamental Sociology, 2014 
any one to imagine an ideal public, which leaves the freedom and choice of individuals in all uncertain matters undisturbed, and only requires them to abstain from modes of conduct which universal experience has condemned. But where has there been seen a public which set any such limit to its censorship? (Mill, 1977: 283-284)

We approach to the moral point of view at the very moment when we begin to commeasure the compatibility of our maxims with maxims of other people. (Habermas, 1995: 14)

By inheriting Aufklärung's belief in reason, German sociologist and political philosopher Jürgen Habermas (1929) formulates the modernity project as the emancipation of our communicative potential. He considers one of the most fundamental problems of the twentieth century to be the crisis of communicative rationality, that is, of our ability to coordinate our claims and intentions by means of intersubjective communication. In his Postnational Constellation, he writes:

... look at the gruesome features of a century that 'invented' the gas chambers, total war, state-sponsored genocide and extermination camps, brainwashing, state security apparatuses, and the panoptic surveillance of entire populations. The twentieth century 'generated' more victims, more dead soldiers, more murdered civilians, more displaced minorities, more torture, more dead from cold, from hunger, from maltreatment, more political prisoners and refugees, than could ever have been imagined. (Habermas, 2001: 45)

Starting from the 196os, Habermas works over the concept of communicative rationality that he suggests to be a normative ideal of any social interaction. In a general outline, communicative rationality is an intersubjectively-oriented rationality embodied in communicative activity that can take the form of procedural argumentative discussion, and aims at finding mutual understanding. This type of rationality implies a mutual clarification of alternative positions where all concerned sides are fully engaged, a mutual openness to criticism, an intersubjectively-oriented process of norm acceptance and decision making, and an orientation to mutual coordination of social interaction. ${ }^{1}$ Communicative rationality is ideally thought of as a guarantee against communicative deformation, dogmatism, instrumental manipulations, and unjustified power domination, or, in other words, against all manifestations of egocentrism, or, as Habermas calls it, subjectcentrism. Totalitarianism, dictatorship, aggression, manipulation of mass conscience by today's media, fundamentalist terror, or forceful globalization are such modi of social and political life that deform principles of communicative rationality.

1. In Theory of Communicative Action Habermas postulates that communicative rationality does not refer to a worldview, but resides in the subjects' ability to clarify their positions, to perceive arguments of another side, and to be open to criticism (Habermas, 1984: 18, 25). 
The postwar situation, when all communicative bonds were severed, urged Habermas to seek new forms of solidarity. Tragic consequences of radical nationalism and permanent ethnic wars, mass migration of refugees, postcolonial poverty of "third world" countries, and national and international terrorism impel him to raise the question whether humankind can still imagine itself to be a kind of community. In trying to answer this question, Habermas elaborates a model of transnational, cosmopolitan, and a moral-legal community of limitless communication. ${ }^{2}$

I will briefly outline what this community model looks like. Communication in this community is supposed to be an open, mutually-oriented argumentative practice. It implies that mutual interpretation, clarification, and justification will prevent the monologism and dogmatism of our claims, intentions, and motivations. This kind of rationality, which resides only in our ability for argumentation, is construed as necessary for all participants of communicative discourse. To be open for argumentation (for producing arguments and receiving argumentative criticism) means to be moral in a Habermasian (formal, logical, and deontological) sense. If a social norm pretends to be (intersubjectively) universal, it should be deliberately, argumentatively, and justifiably accepted by all concerned with this norm. A community of limitless communication resides in the public sphere. ${ }^{3}$ Public space creates the conditions for open argumentative practices. It allows resistance to the domination of powerful institutions, to the manipulative control of media, and it encourages open and mutually-oriented free-will formations.

The communicative ethos of such a community model was designed to prevent new forms of fascism in Europe, to stop routine violence, unwarrantable war interventions, unilateral ambitions of modernization, and fundamentalist terror, and by that, to compensate for the deficiency of democracy and democratic legitimation. In this article, I aim to show what a community of limitless communication is: (1) how its structure of intersubjective interaction functions, (2) in what way its implicit logic of limits can be embedded in our intersubjective claims, and (3) in the ways we interact with each other. By the limit, the principle notion of my reasoning, I understand the formal, logical, and imaginary borderline that separates one autonomous subject (a person, a party, a community, a nation, or a state) from another. I will try to show that the ethics of intersubjective limits is a core framework of the Habermasian community model, and that indeed it plays an essential role in our everyday, social, and political communications. ${ }^{4}$

2. "Community of limitless communication" is a concept also widely used by K. Jaspers, H. Arendt, Ch. S. Peirce, G. H. Mead, and within quite another tradition, G. Bataille. Habermas' specific usage of this term implies moral-legitimate foundations of the community, and argumentative practices providing these moral foundations.

3. Though it is not necessarily broadly public, it can be a local community too, or a spontaneous community of people resolving a conflict through communication on communitarian basis. Its public character resides in the mutual openness itself required by intersubjective perspective.

4. In this article I do not aim at reconstructing the principles of argumentative discussion lying in the spotlight of Habermas' theory of communication. I am interested in what is unfairly deprived of critics' attention, though not less important aspect of his theory, namely, in how we can constitute ourselves and interact with others on/through intersubjective limits, and what these limits mean for our self-actualization. 
First of all, while speaking of the supranational cosmopolitan community in an Habermasian sense, we deal with a community that does not separate itself from other communities by distinct limits; it has no limits at all, not only because it is primarily an imaginary projection, but should it be empirically embodied, it would not have unchangeable limits. It is not attached to a territory or to an institution. To a great extent, the European Union as a supranational, institutionalized organization correlates with Habermas' theory of multinational moral-legal community. ${ }^{5}$ Habermas conceptualizes this imaginary projection as a normative model of the universal moral community in a sense of morality I clarify below. It can (and ideally, in the latest works of Habermas, should) embrace all humankind in its scope. ${ }^{6}$ Any person capable of rational, that is, argumentative, discussion may become a member of such a community. As there are no community limits, one cannot be "excluded" from it unless they want to leave it themselves, and proclaim their non-participation in the communicative process.

We can assume that the community experiences its limits when communication stops or breaks, or starts to function in a deformative (asymmetrical) way. Each time we find ourselves capable of constituting an "ideal communicative situation" (that is, a situation free from any domination except that of the best argument accepted by all concerned), a community of limitless communication emerges. Such a community reveals its contours in each concrete communicative situation purposed at a mutual understanding. This community reorganizes each time when a new participant appears, or a new claim arises. In The Inclusion of the Other Habermas speaks of a "universalism that is highly sensitive to differences" (1998: xxxv). "The community thus constructively outlined is not a collective that would force its homogenized members to affirm its distinctiveness. Here inclusion does not imply locking members into a community that closes itself off from others. The "inclusion of the other" means rather that the boundaries of the community are open for all, also and most especially for those who are strangers to one another and want to remain strangers" (Habermas, 1998: xxxvi). To sum it up, Habermas' community of communication is a movable, transformative community, and sensitive to new extensions and configurations limits.

G. H. Mead also states that this community is a "secondary" one. This means that it does not coincide with national, ethnical, or state limits, and is constituted "above" social order." Secondariness, in this case, implies not an inferiority with regard to the more "superior" society, but a particular zone of modulability of social relationships based on al-

5. On this matter, see, e.g., Habermas, 1998: 103-161, 2001a: 58-112, 2006: 147-179, 2012.

6. See, e.g., Habermas, 2011: 82-96. In many cases he construes community as a pragmatically oriented instrument serving to solve conflicts or to accept an intersubjectively valid norm. It can be, then, practiced as a spontaneous community of quotidian communication, a local ethnical or confessional community, a political community of a nation or an international cosmopolitan community.

7. Habermas adopts Mead's idea of the secondary community. According to Mead, the secondary community of limitless communication constitutes itself "above" determined social order which is more parochial in comparison to the universal secondary community. An individual can become a member of such secondary community in order to mutually resolve a problem, change a behavioral pattern, or redefine intersubjective values. 
ternative, rather than societal, principles. This particular, though not limited, zone is constituted through rational intersubjectively-oriented communicative practices. In contrast to the more emphatic natural character of Tönnis' community, the secondary community has a more "artificial," a more rationally organized, and a more ethically imperative character than an often-spontaneous, unpredictable, and prone-to-strategic-manipulations society. From the other side, we can think of such communities in the plural, that is, communities that can emerge in any social, political, or geographical zone where "ideal communicative situations" are possible. ${ }^{8}$

A paradoxical moment in Habermasian communitarian theory occurs when this model of "exteriorly" limitless community is based on a very specific and challenging logic of "inner" intersubjective limits "within" community. In order to explore this "inner" limitary space, I suggest to imagine it as a formal, logical drawing of intersubjective relationships where we can clearly see how different participants of interaction correlate with each other in their claims. For this purposes, we should address the essential problem, for Habermas, of differentiation between "exterior" and "interior" worlds, which is often unfairly omitted by researchers.

The problem of confrontation between these two categories, that is, the "interior" world of subjective verity and the "exterior" world of others (other subjects and their verities) appeared first in John Stuart Mill's famous work On Liberty (1859), although not described in such terms. Mill first drew this ethical demarcation line between the universal and the private, that is, between social good, and the individual's right to distinguish what is good or bad for the individual by themselves. He first endows the individual with the right to refuse from the "apparently good" social good. He advances an ethical imperative, according to which society should not interfere into the private life of the individual. However, he also prevents the absolutization of a private value as a universal one; it would be ethically wrong if one individual decides for (an)other adult and independent individual(s) what is good or bad for them, and by that, extrapolates one's own values, opinions, and evaluations onto the life of (an)other person(s).

Mill starts his reasoning with the question of limits: "What . . . is the rightful limit to the sovereignty of the individual over himself? Where does the authority of society begin? How much of human life should be assigned to individuality, and how much to society?" (Mill, 1977: 276). He is saying that in all our judgments and evaluations, we should clearly distinguish limits between what "we do not like" or what "does not satisfy our taste preferences", and what is a delinquency or can do harm to society. We have the right to interfere into another person's life when and only when the person transgresses a social norm, violates other peoples' rights, or damages the social good. If a person does not violate the juridical interests of others and carries out their social responsibility, we may feel disapproval towards them, or not endorse them. However, on the interactional level,

8. As we show later, it does not contradict the idea of a universal international community in the scope of the mankind, or as Habermas calls it in his latest work, a "cosmopolitan reunion of the citizens of the world" or "world community with political constitution," etc. The difference is that communities in plural, each with its own particular ethics, can coexist within a larger "planetary" community of universal morality. 
we may only refuse to communicate with them, or limit ourselves in this communication: "We have a right ... in various ways, to act upon our unfavorable opinion of any one, [yet] not to the oppression of his individuality, but in the exercise of ours" (Ibid.: 278).

Mill elaborates such a model of an attitude towards others when we should imagine ourselves as an individual and as a representative of society at the same time. I, as an autonomous individual, should be defended from an unjustified interference of society. I as a representative of society, in general, should not be allowed to interfere in the personal interests of other members of the society. I, as an autonomous individual, should know how to stay within my limits, and should see limits of my evaluations and judgments projected onto another autonomous individual. I, as a representative of a society which imposes norms, should see limits of social interference in another person's life. Such a limitary lens proposed by Mill teaches us to understand that my opinions, convictions, and positions are contiguous with others' opinions, convictions, and positions, and none of them, mine or theirs, is more significant, or "veritable" than that of the other side.

Mill very precisely, or one might even say "graphically," delineates the space of limits between various individuals or communities, each of whom have a pathological propensity to interfere into the other's sphere of life, and to violate their limits. By formulating such ethos of social (interpersonal) credo, he clearly distinguishes limits between what I have right to think and to feel about others, on the one hand, and what I have right to explicitly address, impose, or require from them, on the other hand. We can therefore draw the conclusion that the acknowledgement of limits between having an opinion in regard to others, and advancing one's claims to others by requiring them to give an account of their position, or to redefine it is a litmus test for any mature democratically-oriented liberal society that values equal rights and the freedoms of its members.

Pathology (Mill does not articulate his diagnosis in such terms, but Habermas does ${ }^{9}$ ) consists in the fact that, as history often shows, our very notion of Good can be pathological in itself. Its source is usually our immediate psychical, inherent, and proper thoughts, convictions, and feelings which are deeply rooted in our egocentric "me." Very often, while speaking about the "social good," we unscrupulously mean that our own intuitive sense or notion of good, with an applicability to the exterior world that does not presume any limits. In other words, we do not allow others to have alternative views, not because we are authoritarian (or not in the first place at least), but just because we refuse them the epistemological ability to have equally valid conceptions of good. 'Good for me' is, by default, good for all others, just for the reason that it is good in my opinion. All totalitarian, missionary-religious, and conservative-patriarchal ideologies were (and some of them still are) based on these principles of "natural" expansion and the export of proper "good" ideas, values, and intuitions into other peoples' worlds. ${ }^{10}$

9. See Habermas, $2001 b$.

10. Here it is worth reminding us of Th. Hobbes saying, "To this war of every man against every man, this also is consequent; that nothing can be unjust. The notions of right and wrong, justice and injustice, have there no place. The notions of right and wrong, justice and injustice, have there no place. . . It is consequent also to the same condition that there be no propriety, no dominion, no mine and thine distinct" (Hobbes, 1996: 85; put in italics by me-T.W.). 
We remember Kant's imperative that "each person is to have an equal right to the most extensive basic liberty compatible with similar liberty for others” (Rawls, 1985: 227). Two centuries later, Habermas repeatedly reproduces this formula in communitarian terms by saying that none can have freedom if the (other) members of a community do not have freedom in the same way. ${ }^{11}$ Mill first demonstrates that the notion of good may be used in plural. My notion of good is as particular and as conditioned as everyone else's. To generate a unified conception of good for a society, or even for a supranational community, is a much more challenging task if we are concerned about what logic of intersubjective limits is implied in this unified conception (or how exactly it can be absent there).

An essential ethical moment, which can be drawn out of Mill's reflection, is that we can measure ethical character of a judgment according to the means used for addressing this judgment of others. In other words, according to the logic, this judgment is implemented in an intersubjective space. Mill microscopically analyzes this complex, (indeed elementary, but often undistinguishable, and therefore complex), logical mechanism. He systematically calls violence the good that is imposed on others by force, or by an unjustified interference into their private sphere of life. Social good, when being forcefully introduced into individuals' lives, turns out to be evil in its essence. Whether a judgment can be regarded as good or evil can be defined by the attitude that the person making the judgment has towards the other's limits. In case the person neglects these limits and imposes their good by force, for Mill, the protest against the interference is justified, as it would be then a protest against evil. In other words, evil is not something that is "objectively bad." Mill produces a "subjectively conditioned" image of evil, an image which, before him, had not been articulated. The "subjective" nature of evil derives from the means we refer to other's limit; he writes, "All errors which [a person] is likely to commit against advice and warning, are far outweighed by the evil of allowing others to constrain him to what they deem his good" (Mill, 1977: 277). From this, it follows that evil is just a particular opinion or position that claims to be a universal norm being imposed by force, or without being justified by those concerned.

Mill gives two examples that demonstrate this (in)distinguishability of limits. In order not to go too deeply into detailed accounts, let us reconstruct the formal logical structure of the examples. Muslims consider an action "X" to be immoral both for Muslims and Christians. Catholics consider an action "Y" to be immoral both for Catholics and Protestants. If we take the position of the Muslims, we have the right to persecute Christians; if we take the position of the Catholics, we would have the right to persecute Protestants. Mill draws the following conclusion:

... if mankind are justified in interfering with each other's liberty in things which do not concern the interests of others, on what principle is it possible consistently to exclude these cases? or who can blame people for desiring to suppress what they regard as a scandal in the sight of God and man? No stronger case can be shown for prohibiting anything which is regarded as a personal immorality, than is made out

11. See, e.g., Habermas, 1991. 
for suppressing these practices in the eyes of those who regard them as impieties; and unless we are willing to adopt the logic of persecutors, and to say that we may persecute others because we are right, and that they must not persecute us because they are wrong, we must beware of admitting a principle of which we should resent as a gross injustice the application to ourselves (Mill, 1977: 285).

To conclude, Mill discovers a very important principle formulated more than one-and -a-half centuries ago, and is continually violated in practice everywhere by everyone; the indistinguishability of limits between what refers to the private life and personality of the individual, and what touches upon universal morality and social good. We suggest calling it the pathology of egocentrism, which can be defined as the incapacity to distinguish or the intentional obliteration of intersubjective limits conditioned by the imagined absoluteness of one's own good or one's own conception of good, and the logical, or political, expansion that follows from this position. Egocentrism implies the reduction of the exterior world to one's own personal interests, the perception of one's own interests as unconditionally valuable. It "naturally" entails an unwillingness to recognize other persons' limits. Being introduced into the sphere of intersubjective interaction, this principle of the absolute significance of "me" (my ego, my proper convictions, judgments, values etc.), encourages me to infringe upon other people's limits, and to subjugate logically- and geopoliticallyalien territories. ${ }^{12}$

Though he does not make explicit reference to Mill, it is evident that Habermas borrows his logic of demarcation between the private and the universal. Private individual will, individual verity or logic, is what the individual considers or has the right to consider as "real" and "veritable" for themselves (within the limits of their lifeworld and worldview). As soon as we enter into the sphere of intersubjective relationships, we can-

12. To finish up with Mill, it is necessary to make a brief remark on a subject that nevertheless requires a full-fledged, separate research. Mill does not pose the problem of who and how will be interpreting concrete contextually conditioned questions of limits between what may be admitted as individual tastes, and what is doing harm to society. For example, is erotic photographic art an affair of private taste, or pornography insulting social morals? There was, for example, a famous case in the Soviet history of art, when a successful renown photographer (Alexander Grinberg) was sentenced by the Soviet regime to five years in the working camps as a result of a sudden reinterpretation of his photographic art by the authorities. "One can hardly imagine,-writes about him a Russian researcher of photography Victoria Musvik,-in which direction Alexander Grinberg's work would have developed, but the State suddenly interfered in his life. In 1935 one had an illusion that the state control over photographic art mitigated. Grinberg showed his naked models on the Moscow Exhibition of Masters of the Soviet Photographic Art. On this exhibition he was presented as a member of jury ... In 1936 he was arrested for the 'propaganda of pornography' and sentenced to five years of camps" (Musvik, 2012: 22-23). Almost a century later, we face the same problem of interpretation in Russia with regards to homosexuality. Whether the latter is an expression of individual tastes and preferences, an expression of a life style in a liberally oriented democratic society, or an insult made to social morals, is a question of interpretation. Whether it should be publicly accepted or may be (in terms of repressive liberalism) regarded only as a private though not socially desirable practice, is a question of interpretation. How we draw the borderline between the "moral" and the "immoral," and the "harmful" and the "harmless," influences the borderline between what will be considered as the "private" and the "public," what will be allowed as social good, or defended as a social evil. I am thankful to Alexander Filippov, who suggested the idea that Mill does not see the mechanism whereby those who establish a monopoly for interpretation gain the social power to judge, and to draw constituting borderlines. 
not only pursue our own ends anymore, though we have the right to argumentatively convince others in our position. If we claim that a norm should be intersubjectively accepted, (whether it be a norm of knowledge, or a relationship of behavioral patterns), we have to take others' opinions, interests, and perspectives into account, and presume that a norm should not be accepted unless all concerned agree on that norm.

Habermas makes the very logic of demarcation explicit between what refers to me personally, and what can be intersubjectively justified and valid. In most cases of our quotidian, social, and political life, this limit blurs; it is not recognized or is intentionally disavowed on various pretexts. It seems plausible that most of conflicts have this indistinguishability as their initium et causa. Should we reconstruct the long history of human conflicts and traumas, we will see that the inability to pass from the egocentric to the intersubjective interpretation of the reality lies in the foundations of most of them. Any explicitly advanced claim puts the subject in relation to the limits of the Other. Whether it be a geopolitical ambition, an unwarranted claim for a social status, or someone's authoritarian will within a family, we always experience this tension between my own and the other's limits. In the context of the intersubjective lifeworld, where we are more-thanone-person (where the other, others, we, and society emerge), this borderline sharpens as each of us projects their own logic of limits (or of its all-effacing absence) onto the exterior world of others. Each of us is inclined to interpret limits, or to not notice them, in their own way.

Besides Mill, Habermas (2003: 110) first accentuates this epistemological disposition with regard to limits as an essential and problematic one: "We still lack adequate concept for the semantic difference between what is morally wrong and what is profoundly evil" [earlier in the text-the notion of "radical evil" from biblical language-T.W.]. That is, we do not differentiate between a situation, which we like or dislike for personal reasons, from a situation where our intersubjective rights and freedoms are violated. Let us schematically consider the following case; $S_{1}$ is at variance with $S_{2}$ in their interests. $S_{1}$ claims that $S_{2}$ redefines his or her position, and is ready to accuse $S_{2}$ that he or she is morally wrong. However, if the position of $S_{2}$ refers to him or her only and is not imposed on another $S_{n}$ against their will, the position of $S_{2}$ cannot be considered as morally wrong with regard to $S_{1}$, no matter how much $S_{1}$ disagrees with it. Moreover, if $S_{1}$ intends to redefine the position of $S_{2}$ by force of authority, the action of $S_{1}$ should be evaluated as a violation of their individual rights.

What is "morally wrong" refers, in this case, to the intersubjective morality implying that we mutually recognize the rights and freedoms of each other. What is "essentially wrong" refers to ethical values and judgments that may be different for each of us. These are two heteronomous plans that Habermas suggests not to mingle. In order to understand the specificity of this demarcation, we should start with a simpler differentiation between the exterior and interior worlds, though which is not easy to implement into interaction practices. The simplicity of this division is only all the more apparent as it is usually not articulated in our basic morals and habits. In a broader sense, the interior world refers to our subjective feelings, thoughts, and values. The exterior world refers to 
surrounding contexts, events, phenomena, and relationships with other people. It also includes our actions and expressions addressed to other people. ${ }^{13}$

Habermas conceptualizes this demarcation between the interior and the exterior worlds. The interior world can be distinguished only against a background of the exterior one. The very notion of the subjective world makes sense when and only when we have a sphere of the social "universal" for reference. We only can perceive the subjective world of others in an abstract way, referring to a sphere of the non-universal, or the non-common (Nicht-Gemeinsamkeit). We do not have direct access to it, and cannot judge it according to criteria of the common universal world. It can be thought of only in reference to the world of common order. ${ }^{14}$

Habermas needs this opposition to show that the world of subjective experience (judgments, feelings, and beliefs) and the world of intersubjective meanings are based on absolutely different grounds. Violation of or insufficient attention to this borderline entails both painful and illegitimate communicative deformations. Returning to the example schematically explicated above, if a religious person imposes a meaning of their subjective world as a norm on a non-religious person, it would mean a shift and a violation of the limits between the interior world of subjective meanings, and the exterior world of intersubjective meanings. In reverse order, if a non-religious person forces a religious one to renounce their religious convictions on the ground that "they are essentially wrong," it would mean a shift and a violation of limits between the interior world of subjective meanings (secular mentality), and the exterior world of intersubjective meanings (freedom of conscience).

The decision of a state to legalize weapons can be construed as an "essential evil" in another state's eyes. However, it will not be morally wrong from the intersubjective perspective, each taking the autonomy of the other as a basic presumption. The decision of a liberal community to legalize abortion can be construed as an "essential evil" for a Christian community, but it will not be morally wrong from the intersubjective perspective, each taking the autonomy of the other as a basic presumption. In such cases, we may judge something as "essentially wrong or right" and it will be our private subjective conviction (or a conviction of our parochial community). But it turns out to be "morally wrong" when and only when, being a matter of taste or a subjective verity, it pretends to have an intersubjective meaning without an argumentatively sufficient, intersubjectivelyaccepted justification.

For Habermas, the differentiation of limits between the subjective and the intersubjective is a guarantee from communicative pathologies, that is, from manipulations and intrusions into a private sphere of an individual or a community. In a historical perspective, as previously stated, all totalitarian and authoritarian regimes were (and some of

13. According to Weber's definition of social action as an action oriented towards the Other.

14. He speaks about it, for example, in Habermas, 1984: 43-74, 2008: 24-76. This differentiation can sometimes be found by Habermas as a conceptual separation between propositional verity, subjective authenticity, and juridical validity. Propositional verity is the common knowledge of the "objective world" or facts; subjective authenticity refers to the purely subjective inner world; juridical validity refers to intersubjectively shared and acknowledged norms. 
them still are) based on this assumption of non-differentiation. In extreme cases, this non-differentiation conditions violence, aggression, and destructive transgression; on a discursive level, it can, by default, legitimize ignorance, non-understanding, or discursive domination.

To continue, we can define a relationship in which the limits between the subjectively veritable and the intersubjectively justified/valid are recognized, clearly differentiated, and not violated as "moral." In this case, it is taken for granted that a person may judge others' values and tastes as "essentially wrong," but may not interfere into a private life with their own ethical values and judgments, or redefine others' positions. We can logically conclude that if a conflictual situation between them arises, they ideally should base their strategies of conflict resolution on this initial differentiation before they go into a deeper essential controversy.

Issuing from this initial differentiation, morality and ethics should be also differentiated and constituted in two different plans, according to Habermas. Morality is a set of common regulative principles of social interaction. Ethics is a private domain of values and orientations of an individual or a community within a larger community (society, state, or cosmopolitan community). Morality is a set of normative rules that coordinates intersubjective interaction. Moral principles articulate what can or should be accepted as an intersubjective norm. Ethics expresses a parochial idea of what good is, or what it should be, depending on cultural traditions, and the epistemological contexts of a particular individual or a community. What is ethically good for one person (community) can be not at all good for another person (community). Yet, morality is the "neutral" regulative force that coordinates interaction between all these different persons and communities with their different ethical values, preferences, and claims. We need morality, writes Habermas (1994: 47), "that rests only on the normative content of universal conditions of coexistence in a society (founded on mutual respect for persons)".15

Habermas deduces this logic of differentiation between morally right/wrong, on the one hand, and ethical good/evil, on the other, from the pluralistic nature of modern society. A great number of communities heteronomous to each other (national, ethnical, confessional, political, etc.) have to share a common space, common resources, and coexist with each other. At the same time, he suggests this differentiation to be employed as an instrument of the analysis and correction of social pathologies. Communities and other participants of political and cultural life enter into conflict contradictions with each other, and encounter a lack of a common universal language. Therefore, as Habermas writes, "in modern societies, moral norms must detach themselves from the concrete contents of the plurality of attitudes toward life that now manifest themselves" (ibid.).

In such a way, (by philosophical means), a "secondary" community is modeled in modern Europe which, from one side, does not have national limits, but, which, from the other side, generates a clear logic of intersubjective limits, an ethos of limits, and a

15. As he precises, moral position does not express any axiological orientations; it can only make clear to what extent claims of a particular point of view may be accepted as intersubjectively legitimate. Morality does not coincide with the notion of social good in this sense; it is purely formal, logical, and deontological. 
limitary conscience. The paradox exists in the fact that participants of this community perceive themselves as limited by others and (co)limited with others, while at the same time being at the same time an agent of limitless communication. This very combination of simultaneously open- and restrictive-limits seems paradoxical in the sense of being open-to-others, and restrictive with regard to others. This new European identity of the limitary subject implies that the subject discerns and acknowledges limits of other subjects; they (the subject in question) are, in a sense, produced by these limits. The subject in question is limited by their own ethical orientation and values. They are (co)limited by the same subjects, but are, at the same time, included in a community of limitless communication with (co)limitary others. In such a way, an ideal community of nations, cultures, confessions, political parties, and individuals is to be construed and constructed.

This structural logic of limits is essential for limiting egocentric worldviews, that is, worldviews concentrated on the individuals' or local parochial ego, and incapable of taking the perspectives of others into account. The fact that others are there constrains us in our limits, and reminds us of the limits between us and others. Ideal communication, (in an Habermasian sense), always implicitly implies these significant limits. ${ }^{16}$ But limits do not only divide us, they also, as we have seen, weave social tissue by interconnecting us. As soon as we acknowledge others as others, we enter into a relationship with their otherness. We find ourselves ready to restructure our relationship with others, and to conscientiously draw new information from the way limits are structured in our life worlds. From this point of view, limits are the very core of our human community; they make us (distinguishable) humans among other humans.

To master the principles of this hierarchical system of limits would be essential for the morphologically-complex and heteronomous Russian society, and its social, political, national, ethnical, and confessional inhomogeneity. Within a long period of Soviet history, Russia had the tendency of a centralized, ideologically-authoritarian model of social interaction. Norms were hierarchically imposed on all spheres of life without presuming any alternatives. When the limits to the exterior world were opened, Russia began to experience this tension of intersubjective (international and intercultural) limits. For Russia as a political subject, it is, thus, very important to see and to acknowledge itself limited by others, and (co)limited (together) with others. Russia's attitude towards international norms, and the interpretation of international norms depends on a great extent of this perception of itself as a (co)limited subject.

The same can be said about the internal politics within the country. For example, in taking commonly significant decisions or elaborating commonly valid laws, Russian society could orient itself not only on the axiology of traditional values and stable or even dogmatic authorities, but take the heteronomous ethical orientations of different communities into account. The Government could encourage analytical groups to investigate

16. In his interview "Conversation about God and the World," he uses the notion of the "decentred idea of normativity" that implies that we can only accept something as a norm when we take the perspective of all concerned into account, that is, when we see ourselves us as limited by others. See Habermas, 2006b, or, 2002: $147-167$. 
empirical cases when ethical values of certain social groups are presented as "commonly accepted" and "intersubjectively shared" to the detriment of other groups' values and orientations, when certain social groups extrapolate their axiology to the whole of Russian society while others do not have effective instruments to stand up for their limits, and, by that, do not have instruments to realize to what extent a heterogeneously complex Russian society is based on mutually exclusive principles.

Public articulation of this difference between the "subjective" and the "intersubjective," the "ethical" and the "moral," the "veritable" and the "legitimate," or to put it more simply, between me and Other, could contribute to a more productive mutual clarification of heteronomous positions, values, and interests, and as a consequence, to a better resolution of social and political conflicts, to the mitigation of social tension, and to the creation of non-exclusive social relationships. It could give us an opportunity to listen to heretofore mute and unnoticeable different voices. As Jean-Luc Nancy formulates it (2001: 12-13), "We should go out from the monotheism of thought, as ... we do not conceive this world in terms of Unity anymore."

\section{References}

Habermas J. (1984) The Theory of Communicative Action, Vol. 1: Reason and the Rationalisation of Society, Boston: Beacon Press.

Habermas J. (1991) Erläuterungen zur Diskursethik, Frankfurt am Main: Suhrkamp.

Habermas J (1994) Justification and Application: Remarks on Discourse Ethics, Cambridge: The MIT Press.

Habermas J. (1995) Demokratija, razum, nravstvennost': moscovskije lektsii I interviju [Democracy, Reason, Morals: Moscow Lectures and Interviews], Moscow: Nauka.

Habermas J. (1998) The Inclusion of the Other: Studies in Political Theory, Cambridge: The MIT Press.

Habermas J. (2001a) The Postnational Constellation: Political Essays, Cambridge: Polity Press.

Habermas J. (2001b) On Pragmatics of Social Interaction: Preliminary Studies in the Theory of Communicative Action, Cambridge: The MIT Press.

Habermas J. (2002) Religion and Rationality. Essays on Reason, God, and Modernity, Cambridge: Polity Press.

Habermas J. (2003) The Future of Human Nature, Cambridge: Polity Press.

Habermas J. (2006a) The Divided West. Cambridge, UK; Malden, MA: Polity.

Habermas J. (2006b) Conversation about God and the World. Time of transitions. Cambridge: Polity Press.

Habermas J. (2011) Zur Verfassung Europas: Ein Essay, Berlin: Suhrkamp.

Habermas J. (2012) The Crisis of the European Union: A Response, Cambridge: Polity Press.

Hobbes Th. (1996) Leviathan, New York: Oxford University Press.

Mill J. S. (1977) On liberty. Essays on Politics and Society, Toronto: University of Toronto Press, pp. 213-310. 
Musvik V. (2012) Khranitel traditsij [Keeper of traditions]. Alexander Grinberg: khranitel traditsij [Alexander Grinberg: Keeper of Traditions], Moscow: Art-Rodnik.

Nancy J.-L. (2001) La communauté affrontée, Paris: Galilé.

Rawls J. (1985) Justice as fairness: political not metaphysical. Philosophy and Public Affairs, vol. 14, no 3, pp. 223-251.

\section{Логика интерсубъективных границ в сообществе Ю. Хабермаса (или Почему мы не должны быть единым целым)}

\section{Татьяна Вайзер}

$\mathrm{PhD}$ по социальной философии, преподаватель кафедры общей социологии и социальной философии Российской академии народного хозяйства и государственной службы при Президенте РФ

Адрес: пр-т Вернадского, д. 82, стр. 1, г. Москва, Российская Федерация 119571

E-mail: tianavaizer@yandex.ru

В статье рассматривается модель транснационального космополитического моральноправового сообщества безграничной коммуникации Ю. Хабермаса. Эта модель появляется как попытка философскими средствами выработать гарантии от авторитарных монополий на власть, следствиями которых в XX веке оказались диктаторские режимы и национальные сообщества (про)тоталитарного типа. Проводится реконструкция этой модели наднационального сообщества и анализируется, каким образом в этом сообществе мыслится морально ориентированное интерсубъективное взаимодействие. Показывается, что значимой исследовательской и этической проблемой для Хабермаса является различение границ между «внутренним» (субъективным) и «внешним» (интерсубъективным) миром. Согласно этому различению, субъективная истина или частная ценностная позиция индивида/сообщества может определяться ценностными установками, предпочтениями и вкусами индивида/сообщества; тогда как притязание на истинность (claim), претендующее на то, чтобы быть интерсубъективной нормой, должно быть оправдано и принято всеми, кого эта норма так или иначе касается. Неразличение границ между тем, что считаю истинным лично я, и тем, что должны признавать за норму другие (или навязывание своей партикулярной ценностной установки как универсальной нормы), лежит в основании многих социальных, (гео)политических, этнических, конфессиональных и прочих конфликтов и коммуникативных деформаций. До сих пор критики Хабермаса не уделяли этому аспекту его теории должного внимания. Между тем, именно такое различение между субъективно истинным, с одной стороны, и интерсубъективно валидным, с другой, делает сообщество Хабермаса антитоталитарным и выявляет глубокое этическое значение интерсубъективных границ.

Ключевые слова: Ю. Хабермас, Дж. С. Милль, моральное сообщество, интерсубъективность, внешний мир, внутренний мир, интерсубъективные границы 